Canadian Journal of Higher Education Revue canadienne d'enseignement supérieur

Volume 46, No. 2, 2016, pages 148 - 164

\title{
Incorporating Learning Outcomes in Transfer Credit: The Way Forward for Campus Alberta?
}

Dietmar K. Kennepohl

Athabasca University

\begin{abstract}
Learning outcomes have become an integral part of the global trend in higher education reform and are employed in three interconnected areas: (1) quality assurance, (2) teaching and learning, and (3) transfer credit. The article touches briefly on the first two areas, but focuses discussion on employing learning outcomes in transfer credit. Using Alberta as a case study, its higher education system is examined and assessed, with emphasis on transfer credit, prior learning assessment, student mobility, and system coordination. Both the advantages and limitations of learning outcomes are presented, including balancing the needs of a wide variety of stakeholders. Taking lessons learned from similar international initiatives and an analysis of the Alberta context, the discussion culminates in a proposal for a way forward for this educational jurisdiction, promoting and incorporating learning outcomes as an important component of systematic and transparent method of transfer credit.
\end{abstract}

\section{Resumé}

De nos jours, les acquis d'apprentissage sont parties intégrantes de la réforme de l'éducation post-secondaire à travers le monde. Ces acquis sont abordés dans trois domaines qui sont étroitement liés : (1) l'assurance de la qualité, (2) l'enseignement et l'apprentissage, et (3) le transfert des crédits. Dans cet article il sera question d'aborder brièvement les deux premiers domaines, pour ensuite mettre l'accent sur la façon d'employer les acquis d'apprentissage pour le transfert des crédits. L'Alberta nous servant comme étude de cas, nous étudierons et évaluerons son système d'éducation postsecondaire, en ciblant les facteurs suivants : le transfert des crédits, l'évaluation et la reconnaissance des acquis , la mobilité des étudiants, et lacoordination des systèmes. Nous 
présenterons les avantages et les limites des acquis d'apprentissage, tout en gardant à l'esprit les besoins de toutes les parties prenantes. Nous tiendrons compte des leçons apprises de telles initiatives internationales, et analyserons le contexte albertain. Nous terminerons notre discussion en proposant la voie à suivre à cette région, c'est-à-dire, de promouvoir et d'intégrer les acquis d'apprentissage, et de les adopter, étant donné qu'ils constituent une importante composante d'une méthode systématique et transparente de transfert de crédit.

The learning outcomes movement has been at the forefront of a lot of lively academic discussions and genuine restructuring within higher education systems around the globe. The underlying motives leading to both their creation and use varies somewhat by jurisdiction. For example, their development in Europe, through the Bologna Process for universities and Copenhagen Process for vocational colleges, were motivated by a desire for mobility in work and education for European citizens. On the other hand, in the United States developing learning outcomes resulted from a strong sense of public accountability precipitated by the Spellings Commission, which demanded institutions have clearly articulated outcomes coupled with evidence that students had attained them. Whatever the initial impetus was to employ them, describing learning outcomes (along with assessment of the outcomes) has become the vehicle by which many institutions and educational jurisdictions describe quality (Hazelkorn, 2015; Douglass, Thomson, \& Zhao 2012).

Learning outcomes are usually employed in three areas: (1) quality assurance, (2) teaching and learning, and (3) transfer credit. The three are related, and it is important to have familiarity with all three in order to understand any individual one. This article touches briefly on the first two, since there is already a great deal published on them in the literature, and focuses on learning outcomes in the context of transfer credit. To set the stage, some background will also be presented by looking at global trends and examining what is being done in other jurisdictions. The Alberta postsecondary educational system is employed as a case study, and the discussion describes the current situation and challenges in Alberta, including an analysis of lessons learned and perceived missing pieces.

With over two decades experience as an academic and senior university administrator, coupled with one decade sitting on the Alberta Council on Admissions and Transfer, the author draws from his own experiences, those of his colleagues, and findings reported in the literature. The methodology will be one of critical analysis as described by Birnbaum and Bensimon (1983, pp. 59-63). The paper contends that the three areas employing learning outcomes are not only related but can also be mutually supportive and instructive. The areas of quality assurance and teaching and learning are much more developed than the area of transfer credit, and the knowledge of the former should therefore benefit the understanding, acceptance, and use of learning outcomes in the latter. The analysis here further asserts that transfer credit would greatly profit from taking advantage of learning outcomes and argues for and highlights initiatives in other educational jurisdictions where they are being used successfully. Finally, in the context of Alberta, academic culture, and resource limitations, the article culminates in a proposal for a way forward by suggesting a system that builds on existing components and naturally incorporates learning outcomes. 


\section{International Context and Trends}

A recent survey of national qualifications frameworks of 142 countries and territories (European Training Foundation, 2013) showed that many higher education systems around the globe are based on learning outcomes. The Australian Qualifications Framework (AQF) provides an excellent example of one of the more comprehensive frameworks (Australian Qualifications Framework Council, 2013): it presents a united federal front even though the responsibility for education and training is shared between the Australian Government and state and territory governments. In Canada, education, including advanced education, is not a federal responsibility and is legally under the control of individual provinces and territories. However through the Council of Ministers of Education (CMEC) representing all 13 provinces and territories, governments have been working closely together to share best practices, align policies, and represent Canada internationally. One important piece for our discussion that has emerged from the work of CMEC is the Canadian Degree Qualifications Framework describing common high-level outcomes expected at the bachelor, masters, and doctoral degree levels (CMEC, 2007).

In Europe, while each country is currently at a different stage in development of their own national qualifications framework, they have already established a European Qualifications Framework (EQF), which serves as a universal guide to make the national frameworks more understandable between countries. The EQF is meant to facilitate portability of qualifications and therefore enhance the mobility of European citizens. Other parts of the world are also discussing the possibility of larger regional frameworks such as the proposed Asia-Pacific Qualifications Framework (Burke et al., 2009) in the ASEAN-Australia-New Zealand Free Trade Area, which, like the EQF, is intended to enhance student and worker mobility.

In contrast, the USA, which is a major player in higher education, does not have a national framework, yet there is incredible similarity of qualifications, assessment, and accreditation across that country (Burke et al., 2009). In the USA, many of the objectives of a national framework are being met through other mechanisms, such as requirements of regulated occupations and professional associations, as well as state and regional accreditation. They are also developing recognition tools and have had recent success with the Tuning Project, which we will discuss next. In all cases, like the national frameworks, these mechanisms are also underpinned by learning outcomes at the program level combined with their assessment.

The primary activity associated with the establishment of learning outcomes-based assessment is known as Tuning (Tuning Project, 2008). Through Tuning initiatives, academics in a given discipline work together across institutional lines, seeking input from students, employers, and other stakeholders, to reach an agreed-upon learning outcomes framework for various credentials in their field. The institutions then take those broad, program-based outcomes and determine how to implement them at their own institution, which includes the development of courses. The Tuning approach is being adopted in other parts of the globe including Latin America, Africa, central Asian republics, and Russia. Academics and employers working with learning outcomes in their own discipline or profession will more readily assess and recognize qualifications that also have articulated learning outcomes when brought in from outside their own jurisdiction. The learning 
outcome-based approach and involvement of the professions can potentially have a significant impact on credential recognition and transfer credit in countries such as Canada with its sizeable immigrant population.

Learning outcomes were never meant as a method to standardize or create cookiecutter courses, programs, and institutions. Indeed, initiatives like the Bologna Accord and Tuning have been careful not to frame this in terms of fixed "standards"; rather they have championed a faculty-based approach that retains autonomy and creativity in teaching and learning while fostering a common understanding and system to support learner mobility. For example, the Tuning motto states: "Tuning of educational structures and programmes on the basis of diversity and autonomy" (Tuning Project, 2008, p. 13). Also the Bologna Declaration (European Ministers of Education, 1999) clearly affirms it will "consolidate the European area of higher education . . . within the framework of our institutional competencies and taking full respect of the diversity of cultures, languages, national education systems and of University autonomy." (Para. 10). Any learning outcomes and competencies identified are given in general terms or are core to that program, so that institutions can add other areas and their own approach. Neither pedagogy nor curriculum is set. The adoption of a learning outcomes model (and its related core competencies) by academic disciplines, institutions, and states ultimately comes back to transparent quality assurance, improvement in teaching and learning, and enhancing mobility and credential completion through transfer credit.

\section{Quality Assurance or Higher Education as a Business}

While quality assurance depends on the teaching and learning context as a vehicle to improve the student experience, it is also strongly driven by a sense of accountability and the business of higher education (Stensaker \& Harvey, 2006; Ewell, 2008). In some respects, it can also be viewed as a fundamental political process, balancing the interests and views of many stakeholders (Skolnik, 2010). Approaches to quality assurance build on the qualifications frameworks and their learning outcomes mentioned earlier and are well represented in the literature (Law, 2010; Singh, 2010). Still, it is important to recognize the role that accountability and business interests play.

The neoliberal commodification of higher education has drawn attention and uneasiness among faculty for decades, with many questioning its value and its effect on learning (Ingleby, 2015). The notion that higher education is a business at all is provocative to academics. "They [government and public regulatory agencies] seek accountability for funds spent, students served, learning achieved, and research produced, and they look for results in terms of students graduated, jobs secured, and public benefits earned. A startled and resistant academy's cries of 'We are not a business!' are predictable and deafening." (Greenberg, 2004, p. 12). For those heavily involved with students in teaching and research, higher education is generally viewed as much more than just a business. Just like the relationship between patient and doctor or coach and athlete, the relationship between teacher and student moves well beyond a basic financial arrangement.

Yet, even though universities are not businesses, the corporate ethos has permeated higher education. Not only do institutions regularly use business practices to deliver education and meet operational needs, they position and market themselves to students, alumni, professional bodies, government, and potential funders (including industry and 
the general public). Ratings and the ability to quantify institutional quality and the ability of learners are not just a point of pride but have real financial implications for institutions (Hazelkorn, 2015). Governments, in turn, also recognize the link between the economy and higher education, a link that goes beyond any basic social mandate and has more to do with increased national wealth and accountability for public dollars. Higher education is often viewed by government as another business to be regulated and outcomes become another key performance indicator:

With the emergence of the market model and the adoption of private sector management practices in post-secondary education, many jurisdictions have developed systems of performance evaluation to encourage institutional accountability for quality and efficiency, including systems of performance-based funding. The appropriateness and effectiveness of these approaches have been frequently called into question. (Kirby, 2007, p. 14)

Even students may view higher education as a business, whether it is a paid service or a financial investment, where they (and their parents) are interested in establishing a postgraduate career and realizing earnings. The choice of institution is certainly influenced by the perception of its quality and eventual value to their career (Hemsley-Brown \& Oplatka, 2015). However, Canadian universities are more homogeneous than universities in other parts of the world, so other factors like distance from home, financial considerations, and non-academic services also have an impact on university selection (Drewes \& Michael, 2006).

It would seem that the business perspective is clearly present in higher education and that it would favour, if not drive, any feature that describes, quantifies, and measures educational quality and student success. This is not necessarily a bad thing because it also positively reinforces many existing academic institutional processes and initiatives meant to improve the quality the education and success of the learner. Learning outcomes are ideal in this respect and have commanded a great deal of recent attention within higher education (Tremblay, Lalancette, \& Roseveare, 2012; European Commission, 2013). They also have the added political feature of showing accountability and transparency, while seemingly underpinning the learning process itself. However, from an academic perspective how useful are they really in the context of teaching and learning?

\section{Benefits and Limitations of Using Learning Outcomes for Teaching and Learning}

Because of their popularity, there is also a great deal in the literature around learning outcomes, including several helpful summaries and reviews (Nicholson, 2011; Tremblay, et al., 2012). The mechanics of incorporating them in an effective way can often be found within higher education institutions, usually housed in learning resources departments or centres. There are also some excellent user-friendly treatments and practical guides written by those already successfully employing outcomes (Ascough, 2011; Kennedy, Hyland, \& Ryan, 2009). Advantages of this approach include providing a more student-centred learning environment, an increased transparency to the process, a sense of fairness around assessment, and a perception that standards are being met. 
Despite the benefits of using learning outcomes there are also some genuine limitations. The most noticeable one is the lack of consistency around nomenclature. There are a number of related terms applied to learning outcomes, such as learning objectives/ goals, learning outputs, competencies, and student attributes that are defined and used in similar and different ways. Until there is a mutual agreement of meaning, caution and clear working definitions are necessary (Kennedy, et al., 2009). However, this can be viewed as a relatively temporary situation. The more serious criticisms around outcomes often cite its potential for being too process oriented, that it replaces good teaching with templates, limits emergent learning outcomes, is too assessment focused, and removes independence and ownership of learning from the student (Simmons, 2013).

Nevertheless, both the biggest advantage and biggest disadvantage of learning outcomes is that they is set explicit expectations. Simply put: Be careful what you ask for. While outcomes may be written with the best intentions of representing minimum required achievements, it is human nature to sometimes see them as a ceiling of goals to attain or simply the sole focus of a learning experience. In a higher education environment, where we have a lot of bright people, we expect students (and teachers) to explore and not limit themselves or their learning. That expectation should always be clearly communicated. Learning outcomes are required to be tangible enough to be demonstrated and measured. Yet some important outcomes of a good education are difficult to articulate, let alone quantify.

Experience has shown that to take real advantage of learning outcomes one needs to put a lot of thought into their development (Ascough, 2011; Kennedy, et al., 2009). It is a balance of providing tangible sign posts for the learning process, while not prescribing too many details that may constrain the learning itself. In short, properly applied and in the right hands, learning outcomes can be a valuable component of teaching and learning.

\section{Transfer Credit}

The ability for a learner to have prior academic work evaluated and recognized for transfer credit is an important part of a functioning postsecondary system that promotes seamless learner pathways. Establishing to what degree two courses are equivalent is not a trivial exercise. For example, here are two calendar descriptions of chemistry courses that come from the same educational jurisdiction and a summary in Table 1 showing the similar and identical components.

\section{Course A}

This course enables students to deepen their understanding of chemistry through the study of organic chemistry, energy changes and rates of reaction, chemical systems and equilibrium, electrochemistry, and atomic and molecular structure. Students will further develop problem-solving and laboratory skills as they investigate chemical processes.

\section{Course B}

This course introduces concepts of chemistry, the central link between the physical and biological sciences. Principles discussed include chemical bonding, simple reac- 
tions and stoichiometry, chemical equilibria and solution equilibria (acids, bases, and buffers), thermodynamics (energy, enthalpy, and entropy), kinetics (the study of rates of reactions), and redox/electrochemistry, and introductory organic chemistry.

Table 1.

Common Components between Chemistry Course A and B.

\begin{tabular}{ll}
\hline Course A & Course B \\
\hline Organic chemistry & Introductory organic chemistry \\
Energy changes & Thermodynamics \\
Rates of reaction & Kinetics \\
Chemical systems & Chemical transformations \\
Equilibrium & Simple reactions and stoichiometry \\
Electrochemistry & Chemical and solution equilibria \\
Atomic and molecular structure & Redox/electrochemistry \\
\hline
\end{tabular}

From the course descriptions and Table 1 the two chemistry courses appear to be very similar if not identical. Yet, one course is a senior high school chemistry course and the other is an introductory general chemistry course at a university. By itself, the content description does not indicate the level of the course. To be fair, instructors deciding on transfer credit demand much more evidence than just a short course description, and indeed most course outlines submitted with transfer requests provide that information (e.g. textbooks, contact hours, formal prerequisites, instructor qualifications, etc.). In addition, a student evaluation office or office of the registrar would insure that only work from "credible" institutions is even considered in the first place by the academic. Taken together these criteria are heavily course and institution based and describe inputs into the student experience. In the past, the only traditional measure of student outcome was the grade achieved for work done at the sending institution.

In contrast, learning outcomes are student-centred, and as the name suggests, the focus is on outputs. Academics have a good working knowledge and comfort with input measures (such as instructional contact hours) and so it is not expected that this will be abandoned. Even in jurisdictions like Europe where learning outcomes are required and lauded as the building blocks of the Bologna package of educational reforms, they have not moved away completely from inputs. While outcomes are central to qualifications frameworks and shape the diploma supplements that accompany a particular degree, European Credit Transfer and Accumulation System (ECTS) credits (which directly reflect workload hours) play a vital role in validating learning achievements. This combination has been described as a "difficult brew" where "in practice, student workload dominates" inferring that a higher value is still placed on inputs rather than outputs (Adelman, 2009, p. xviii).

Some jurisdictions currently do not even have a systematic process of stating outcomes. In Canada the adoption of learning outcomes has been slow at the university level (Peters, 2006); their adoption is generally more prevalent at the college level. Unlike the 
European system where international student exchanges and student mobility for integration into labour markets is the ultimate aim, in Canada it is more about learner pathways for credential completion of domestic students (FitzGibbon, 2014). The obstacle to having seamless learner pathways has always been implementation of effective transfer credit. Some of this has been due to differences between jurisdictions, but it can also occur within the same jurisdiction, with the most common challenge being transfer from a college or technical school to a university. Possible reasons for reluctance of universities to give transfer credit include perceived value of technical courses, missing high school prerequisite courses, and college reputation. Employing learning outcomes has been suggested as a way to facilitate these sorts of articulations (Carter, Coyle, \& Leslie 2009). There is strong evidence for this perspective when one considers professional organizations (whose members include technicians, technologists, engineers, allied health professionals, biologists, and chemists to name a few) with member certification requirements that state learning outcomes. These professionals tend to have an easier time with mobility and credit recognition within their discipline.

The presence of learning outcomes is clearly an advantage in assessing transfer credit, but they must also be stated in a common language that is understood by both sending and receiving institutions. Colleges and technical institutes will tend to focus on applied knowledge, while universities emphasize theoretical and research knowledge (Carter, et al., 2011). To counterbalance these differences some jurisdictions, including Canadian provinces like British Columbia and Alberta, have set up articulation committees by discipline to promote transfer credit as well as course and program equivalency. These committees provide a forum for exchanging information and enhancing collaboration and coordination among institutions (CMEC, 2012).

\section{The Prior Learning Frontier}

Learning outcomes are also an indispensable tool in the area of prior learning assessment and recognition (PLAR)-also known as recognition of prior learning (RPL). In this case, informal and nonformal learning is considered and assessed for transfer credit. Again, similar to transfer credit of formal learning, this can be assessed on a courseby-course basis or as a larger block of work. In either case it becomes necessary to use outcomes mostly because the usual inputs (e.g. textbook, course outline, contact hours) are not available. The absence of the usual educational input measures has made PLAR a contentious area and often viewed as an inferior higher education experience (Conrad, 2008; ACAT, 2007). The underlying philosophy of PLAR is that it should not matter where or how learning has occurred, but that it has occurred. However, practitioners of PLAR know that this is not a trivial exercise (Harris, Breier, \& Wihak, 2011). One not only needs clearly articulated learning outcomes, but also solid evidence that they have been met by the student. One not only needs to constantly have an open mind about different potential forms of learning but also be rigorous enough to demand proof that learning has occurred. It is paramount to good PLAR practice to give credit for learning rather than just the experience.

Increased student mobility, ubiquitous access to knowledge, and learning trends like massive open online courses (MOOCs) are increasing the demand for PLAR in higher education. Despite an arguably long-standing connection between PLAR and higher educa- 
tion (Conrad, 2008), PLAR with all its accompanying suspicions is really at the frontier of transfer credit. It is here that we will ultimately test and obtain knowledge on how learning outcomes are viewed, trusted, and used. It will not only inform our assessment of informal and nonformal learning assessment in the long run, but most certainly provide muchneeded insight into the role of learning outcomes and current formal learning assessment.

\section{The Case Study of Campus Alberta}

Campus Alberta was built on the growing partnerships between the province's 26 publically funded postsecondary institutions and has become one of the best transfer systems in the country, if not the world (Constantineau, 2009). At its inception in 2002, it was a relatively informal concept that focused on a system-wide approach meant to further encourage collaboration and, more importantly, allow learners to navigate through the system seamlessly. The jewel in the crown of Campus Alberta has been the transfer credit system managed by the Alberta Council on Admissions and Transfer (ACAT), an independent body established in 1974. It includes the Aboriginal colleges and some out-ofprovince institutions as members. The two common approaches to formal recognition of transfer credit in this system are (1) course-by-course transfers and (2) program (and block) transfers. The first approach is meant to assess the equivalency of individual courses, while the second considers a body of work such as a certificate, diploma, or series of integrated courses to ascertain what credit the student would obtain at the receiving institution. The most familiar example of block transfer is the so-called " $2+2$ degree," which consists of a two-year college diploma capped with another two years at a university.
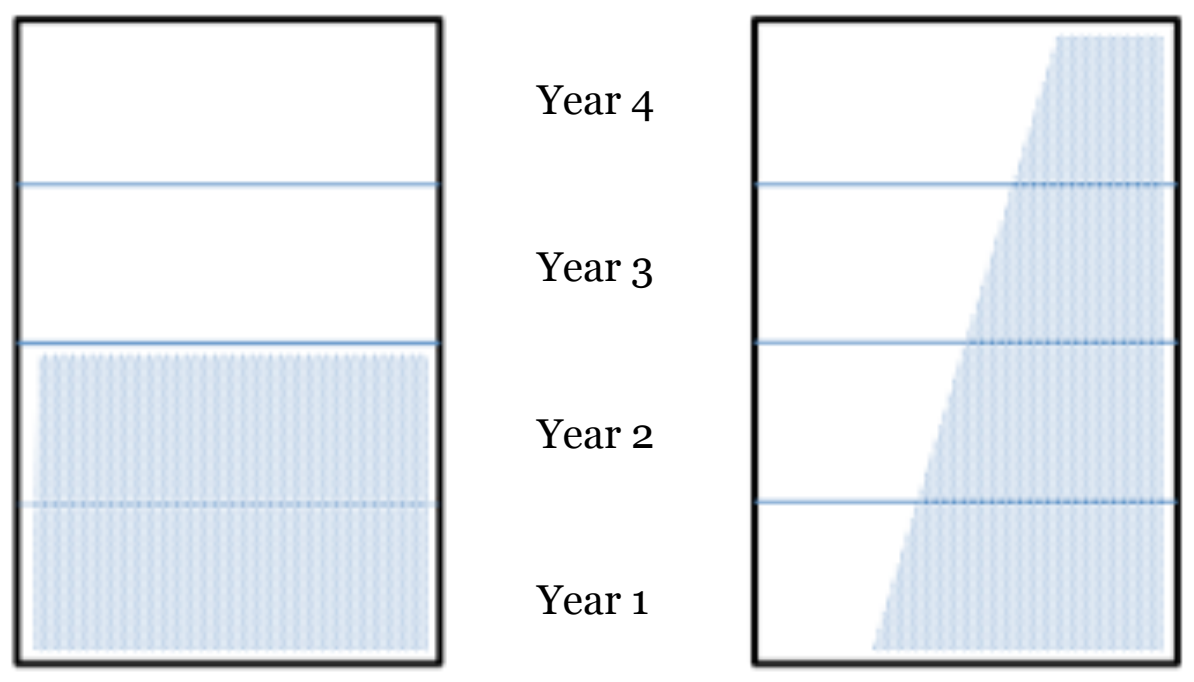

$\square$ College Work

$\square$ University Work

Figure 1. (A) Sequential format (B) Blended format of a $2+2$ degree program

The $2+2$ is often viewed as a simple linear process as depicted in Figure 1(A), which is certainly the case when the college two-year program is designed specifically with university transfer already in mind. However, it may look more like Figure 1(B) if higher level work has already been introduced in the college or technical institute, but some of the foundational courses normally taken in year 1 and 2 are missing. The two-year cap at the university to complete the degree may need to provide a blend of courses at all four years, to cover both 
depth and breadth of the program. In these cases, it is vital to know the learning outcomes of the courses and programs at both institutions in order to identify potential missing pieces. Conceptually, learning outcomes effectively allow those assessing transfer credit to work outside of the usual boundaries created by standard learning units ("the program" or "the course") that are normally given transfer credit so they can recognize a variety of equivalencies and combinations of equivalencies. In our example, we compare a $2+2$ degree from two institutions with a four-year degree from one institution; they may not have one-on-one transferable courses or even courses in the same order within the program, but they are equivalent degree programs because they cover the same learning outcomes.

In 2010-2011 fall registration, the Alberta system had a total of 269,993 students with 19,461 (7.2\%) who had previously attended another institution (Alberta Enterprise and Advanced Education, 2012). This includes 12,472 students transferring within province, 4,980 transferring from the rest of Canada, and 2,009 transferring internationally (ACAT, 2012). An annual student mobility of $7.2 \%$ may seem like a minor component of the total number of students, but at that rate over a four-year period approximately 1 in 4 students completing a four-year bachelor degree at the Comprehensive Academic and Research Institute would have been at another institution as part of their academic career. In addition, annual overall student mobility in the province continued to grow with a relative increase of $1.7 \%$ of the entire system from 2006 to 2011 (a $40.0 \%$ increase in absolute numbers). On the whole, as mobility and demand for transfer credit rises, it becomes much more a part of the regular business of higher education in Alberta. At this point, it is useful to pull together a summary of some of the strengths and weaknesses of the ACAT system within Campus Alberta.

\section{Strengths}

ACAT provides a standard process to establish and communicate transfer credit and offers mediation between institutions on transfer agreements, where transfer considered can be both course-by-course or as block transfers. The council also regularly monitors student mobility and carries out relevant research to help inform its processes and policies. It has a strong student focus and encourages a system-wide approach across the province in order to increase potential learner pathways. Furthermore, ACAT is starting to introduce articulation committees to provide informed coordination by discipline.

Until recently PLAR would have been identified on the above list of strengths. Several years ago there was strong government interest in PLAR, which included province-wide workshops and consultations (ACAT, 2006; ACAT, 2007) that eventually culminated in an action plan for Alberta (Alberta Advanced Education and Technology, 2008). A year later, an Alberta institutions update was provided (Jevne, 2009), but there has been little centralized activity since then. This brings up the question not only of the current PLAR situation in Alberta but also that of transfer credit and learning outcomes.

\section{Weaknesses}

As the system grows, increased workload and lack of funding have become an issue for both the ACAT secretariat and member institutions. There is also a lag in technology for database management and automation, which reduces access and slows processing. Also, while member institutions voluntarily collaborate for the good of the system, there 
is no direct incentive for receiving institutions to articulate transfers. In addition, with its primary focus being provincial, both national and international credential completion and mobility is uncertain. Finally, learning outcomes are simply not used for setting up transfer credit agreements.

In the past 40 years ACAT has developed a cohesive transfer system and accumulated experience (lessons learned) around establishing and maintaining transfer agreements. Still, there are areas where with gaps and much more needs to be done, as reflected in the comments around PLAR and in the identified weaknesses. The first three weaknesses mentioned above (challenges with workload, funding, and database management) reflect administration and logistical challenges as the system has scaled up. Of more relevance to our discussion are PLAR and the remaining weaknesses, which have a more direct connection to learning outcomes. Is the incorporation of learning outcomes in the Alberta system something that is needed or even wanted?

Unlike the area of transfer credit there is a relatively clear appreciation of the role of learning outcomes within Alberta's higher education system in the context of both quality assurance, and teaching and learning. In introducing learning outcomes for transfer credit, there have also been suggestions of how they might be employed and to what advantage. It comes back to the need for a systematic approach to help students meet their needs (mobility and credential completion) that goes beyond traditional inputs.

One can immediately see the usefulness in assessing students' work from outside Alberta (national and international) or for block transfer or PLAR assessment, where sought after, that recognizable inputs may be different or non-existent. It is much less obvious for basic course-level and program-level transfer within the province, because the system is currently functioning using only traditional inputs for assessment. Despite this, there are two good reasons to also use learning outcomes here. First, the approach supports ideals espoused from the areas of quality assurance, and teaching and learning, including better transparency and student centredness. Second, it has the practical advantage of developing a knowledge base and comfort level for working with learning outcomes to inform other assessments that are non-Albertan, block transfer, or PLAR.

In 2011, ACAT carried out an informal survey on learning outcomes for courses and programs with Alberta postsecondary institutions (D. K. Kennepohl, private communication, July 5,2011 ). The extent of their integration and use varied greatly not only between institutions but also between faculties and departments at the same institution. The value of using learning outcomes from a teaching and learning perspective was universally expressed, as were plans to further incorporate learning outcomes for that purpose in the future. The survey never queried institutions about learning outcomes in the context of transfer credit processes. Currently in the ACAT system, learning outcomes are not requested in the documentation of course outlines. The equivalent British Columbia Council on Admissions \& Transfer (BCCAT) transfer documentation prompts sending institutions to include learning outcomes when presenting course outlines, but it is not mandatory.

Whatever future approach is considered in Alberta should be sensitive to institutional and classroom autonomy and workload, and should address apprehension about using learning outcomes. Learning outcomes can be at the institutional, program, and course level and should be consistently linked with each other. Faculty tend to be supportive at 
the institutional and program level, but become more sensitive at the course level where it might infringe on their own teaching (Carpenter \& Bach, 2010). Similarly, institutions resist any outside suggestions at the higher levels that may seem too prescriptive or suggest limitations to institutional autonomy (Weinrib \& Jones, 2014). Balancing autonomy with learning outcomes creation and use is vital in an academic and collegial environment. In addition, any process considered should be efficient, funded, and kept at a manageable level. Faculty already provide their time through internal committee work and volunteer externally reviewing papers or contributing to their own profession. They are more likely to participate if the task is not onerous and they see value in it. Finally, moving to learning outcomes for assessing transfer credit is a substantive change in the usual business for individuals and organizations. The transition needs to be staged and naturally build on what is already familiar to deal with both trepidation and basic logistics.

\section{A Proposed Way Forward}

Even with the Canadian Degree Qualifications Framework providing a high-level overview of expected learning outcomes (university degrees only) across the country (CMEC, 2007), the approaches to using learning outcomes for transfer credit vary between educational jurisdictions (FitzGibbon, 2014). Incorporating learning outcomes within the transfer system has the potential to reinforce their use in other areas such as quality assurance, and teaching and learning. Experience from other educational jurisdictions highlights their approaches and the advantages realized. Although this global trend is recognized, it is significant that higher education in Alberta is already moving in the direction of incorporating learning outcomes at the institutional level. Considering the Alberta context and the strengths already identified, the most obvious way forward is a three-phase approach, which would not only rationally align with learning and quality assurance objectives on the front end but also would build the needed logistical foundations and trust so that learning outcomes are eventually used to genuinely assess transfer credit.

\section{Phase 1: Stating Learning Outcomes}

In Phase 1, individual institutions would continue to develop clearly articulated learning outcomes at the course, program, and institutional level. In addition, because existing articulation committees in Alberta are similar to Tuning committees, there is an excellent opportunity to extend their terms of reference to include identification of the most important learning outcomes that would form a particular credential program. Keep in mind this is a faculty-led consultation with discipline-specific stakeholders (including graduates and employers) who would ascertain critical reference points of a credential to ensure they whould not inhibit the distinctiveness or emphasis of that major. This is an important piece for setting the stage because, while each institution should be autonomous and creative, from a transfer credit context the learning outcomes of the sending institution need to be understood by the receiving institution.

\section{Phase 2: Incorporating Learning Outcomes Locally}

This phase would focus primarily on activities within the institution itself and include full integration of learning outcomes as part of the learning and assessment cycle within 
courses and programs. It would also include developing procedures to collect and analyze evidence that students were meeting stated outcomes of the course, program, and institution and using those results to inform improvements. This phase is about incorporating, being comfortable with, and understanding learning outcomes primarily at the course level and how that also maps onto the program-level outcomes.

\section{Phase 3: Employing Learning Outcomes in Transfer Credit}

The system would increasingly emphasize employing learning outcomes and evidence that they are being met as an important component of transfer credit requests between institutions. Traditional input information would be given to provide context as supplemental information. This phase shifts away from a long history of exclusively employing input measures and could be perceived as a big cultural jump for those assessing transfer credit. To mitigate that jump it would be vital that phases 1 and 2 were well underway and that any transition period would have both input and outcomes information available in parallel for transfer credit assessment.

When examining this three-phase approach, one should keep in mind two important features. First, while the phases are presented in their rough chronological sequence, it is more important to create trust through the phases rather than adhering to an absolute order and timing. Indeed, an environmental scan of postsecondary institutions in Alberta in 2011 indicated that through independent agendas many institutions are already well into Phase 1, if not Phase 2, at the program level. The corresponding course-level work with learning outcomes is only starting. More important, systematic alignment across levels and integration of the assessment piece is not common. The degree of learning outcomes incorporation and use will naturally differ between institutions and even within programs and faculties of the same institution. It is not a lock-step process, which means one could potentially see activity in all three phases simultaneously.

Second, while the great majority of the work deals with formal learning, the three phases also apply to assessing informal and nonformal learning with the intention of recognizing prior learning. Student evaluations of PLAR requests should be based on the same learning outcomes used in formal transfer credit, so Phase 1 would presumably be identical for any given program or course. However, individual institutions would determine what evidence and methodologies (e.g. portfolios, challenge exams, etc.) would be required to show that those outcomes have been met. As previously noted, it is on this PLAR frontier that one may expect valuable insights since issues arising around learning outcomes will be more visible and therefore closely scrutinized.

\section{Conclusion}

Employing learning outcomes in transfer credit assessments provides many advantages including a more transparent and systematic approach, especially when those same outcomes are also used for teaching and learning, and quality assurance. Historically, it has been input measures exclusively that are considered in assessing transfer credit and moving in the direction of employing learning outcomes is seen as a huge cultural change. Still, for a number of reasons the global trend in higher education is towards outcomes 
and this trend is also being seriously considered and applied in Canada. The three-phase proposal to incorporate learning outcomes for transfer credit in this article is built on existing strengths of the Alberta system, which include a well-established transfer system, a good track record of collaboration between postsecondary institutions within Campus Alberta, and existing discipline-specific articulation committees. The intention of this proposed investment in outcomes is to foster seamless learner pathways and credential completion within the system, as well as facilitate student mobility here and abroad.

The process itself is informed by lessons learned from similar international initiatives. Yet, it also needs to be set in the Alberta postsecondary context, one that balances collaboration and system harmonization with institutional autonomy and creativity. Similarly, other educational jurisdictions wishing to use learning outcomes in transfer credit would also need to take into account the context of their own postsecondary system, while still employing fundamental principles such as building on existing structures and phasing in strategic components over time.

The key question that needs to be answered in developing any successful approach in a system of independent institutions is how one can build a comfortably working knowledge of learning outcomes that would foster mutual trust for their use in transfer credit. The phased approach proposed in the Alberta context offers an example of a natural progression forward that will shape how learning is perceived in the twenty-first century.

\section{Acknowledgement}

Thank you to Ann Marie Lyseng and Eric Dohei of the ACAT Secretariat for helpful discussions and the Alberta learner mobility and pathways statistics.

\section{References}

ACAT (Alberta Council on Admissions and Transfer) (2006). Alberta recognizes learning: A forum on prior learning assessment and recognition (PLAR) final report. Retrieved from http://www.acat.gov.ab.ca/pdfs/ARL_FinalReport_December_o6.pdf

ACAT (Alberta Council on Admissions and Transfer) (2007). Developing a prior learning assessment and recognition policy framework: Whatwe heard. PLAR workshop session. Retrieved from http://eae.alberta.ca/media/126765/plarworkshop.pdf

ACAT (Alberta Council on Admissions and Transfer) (2012). Transfer patterns report 2011. Retrieved from http://www.acat.gov.ab.ca/pdfs/Transfer-Patterns-2011.pdf

Adelman, C. (2009). The Bologna process for U.S. eyes: Re-learning higher education in the age of convergence. Retrieved from http://www.eric.ed.gov/PDFS/ED504904.pdf

Alberta Advanced Education and Technology (2008). Advancing PLAR in Alberta: An action plan. Retrieved from http://eae.alberta.ca/media/126762/plaractionplanoct2008. pdf

Alberta Enterprise and Advanced Education (2012). Campus Alberta planning resource 2012: Profiling Alberta's advanced education system. Retrieved from http:// eae.alberta.ca/media/398287/capr2012fulltext.pdf

Ascough, R. S. (2011). Learning (about) outcomes: How the focus on assessment can help overall course design. Canadian Journal of Higher Education, 41(2), 44-61. 
Australian Qualifications Framework Council (2013). Australian Qualifications Framework(2nded.). Retrievedfromhttp://www.aqf.edu.au/wp-content/uploads/2013/ 05/AQF-2nd-Edition-January-2013.pdf

Birnbaum, R., \& Bensimon, E. M. (1983). Maintaining diversity in higher education. San Francisco, CA: Jossey-Bass.

Burke, G., McKenzie, P., Shah, C., Keating, J., Vickers, A., Fearnside, R., \& Bateman, A. (2009). Mapping qualifications frameworks across APEC economies. Singapore, SG: Asia-Pacific Economic Cooperation Secretariat.

Carpenter, A. N., \& Bach, C. (2010). Learning assessment: Hyperbolic doubts versus deflated critiques. Analytic Teaching and Philosophical Praxis, 3O(1).

Carter, I., Coyle, J. P., \& Leslie, D. R. (2009). Improving the outcomes for college students transferring to university. Collected Essays on Learning and Teaching, 2, 54-60. Retrieved from http://ojs.uwindsor.ca/ojs/leddy/index.php/CELT/article/view/3203

Carter, I., Coyle, J. P., \& Leslie, D. R. (2011). Easing the transfer of students from college to university programs: How can learning outcomes help? Canadian Journal of Higher Education, 41(2), 10-27.

CMEC (Council of Ministers of Education, Canada) (2007). Ministerial statement on quality assurance of degree education in Canada. Retrieved from www.cicic.ca/docs/ cmec/QA-Statement-2007.en.pdf

CMEC (2012). Report of the CMEC Credit Transfer Working Group. Retrieved from http://www.cmec.ca/Publications/Lists/Publications/Attachments/311/CTWG\%20 Report\%202012_EN.PDF

Conrad, D. (2008). Building knowledge through portfolio learning in prior learning assessment and recognition (PLAR). Quarterly Review of Distance Education, 9(2), 139-150.

Constantineau, P. (2009). The Ontario transfer credit system: A situation report. Council of Ontario Universities. Retrieved from http://cou.on.ca/wp-content/ uploads/2015/07/Academic-Colleagues-The-Ontario-Transfer-Credit-System.pdf

Douglass, J. A., Thomson, G., \& Zhao, C. M. (2012). The learning outcomes race: The value of self-reported gains in large research universities. Higher Education, 64(3), 317335 .

Drewes, T., \& Michael, C. (2006). How do students choose a university?: An analysis of applications to universities in Ontario, Canada. Research in Higher Education, 47(7), 781-800.

European Commission (2013). High level group on the modernisation of higher education: Report to the European Commission on improving the quality of teaching and learning in Europe's higher education institutions. Retrieved from http://ec.europa. eu/education/higher-education/doc/modernisation_en.pdf

European Ministers of Education (1999). The Bologna declaration. Retrieved from www.ehea.info/Uploads/Declarations/BOLOGNA_DECLARATION1.pdf 
European Training Foundation (May 2013), Global national qualifications framework inventory: Prepared for ASEM Education Ministers Conference. European Centre for the Development of Vocational Training, \& UNESCO's Institute for Lifelong Learning. Kuala Lumpur, 13-14 May 2013 (ASEMME 4). ETF Communications: Torino, Italy. Retrieved from http://www.cedefop.europa.eu/EN/Files/2211_en.pdf

Ewell, P. T. (2008). U.S. accreditation and the future of quality assurance: A tenth anniversary report from the Council for Higher Education Accreditation, Washington, DC: Council for Higher Education Accreditation.

Fiddler, M., Marineau, C., \& Whitaker, U. (2006). Assessing learning: Standards, principles, and procedures (2nd ed.). Chicago, USA: CAEL.

FitzGibbon, J. (2014). Learning outcomes and credit transfer: Examples, issues, and possibilities: A BCCAT special report. Retrieved from http://www.bccat.ca/pubs/ Learning_Outcomes_and_Credit_Transfer_Feb2014.pdf

Greenberg, M. (2004). A university is not a business (and other fantasies). Educause Review, 39(2), 10-16.

Harris, J., Breier, M., \& Wihak, C. (2011). Researching the recognition of prior learning: International perspectives. Leicester, UK: National Institute of Adult Continuing Education.

Hazelkorn, E. (2015). Rankings and the reshaping of higher education: The battle for world-class excellence (2nd ed.). New York, NY: Palgrave McMillan.

Hemsley-Brown, J., \& Oplatka, I. (2015). University choice: What do we know, what don't we know and what do we still need to find out? International Journal of Educational Management, 29(3), 254-274.

Ingleby, E. (2015). The house that Jack built: Neoliberalism, teaching in higher education and the moral objections. Teaching in Higher Education, 2O(5), 518-529.

Jevne, S. (2009). Advancing PLAR in Alberta-an action plan: Report on institution visits. Edmonton, AB: Government of Alberta, Advanced Education and Technology. Retrieved from http://www.acat.gov.ab.ca/pdfs/PLARActionPlanInstitutionVisits.pdf

Kennedy, D., Hyland, Á., \& Ryan, N. (2009). Writing and using learning outcomes: A practical guide. In the Bologna Archive of Journal of the European Higher Education Area (C3.4-1). Implementing Bologna in your institution.

Kirby, D. (2007). Reviewing Canadian post-secondary education: Post-secondary education policy in post-industrial Canada. Canadian Journal of Educational Administration and Policy, 65, 1-24.

Law, D. C. S. (2010). Quality assurance in post-secondary education: Some common approaches. Quality Assurance in Education, 18(1), 64-77.

Nicholson, K. (2011). Quality assurance in higher education: A review of the literature. McMaster University: Hamilton, ON: Council of Ontario Universities Degree Level Expectations Project. Retrieved from http://cll.mcmaster.ca/COU/pdf/Quality\%20 Assurance\%20Literature\%20Review.pdf 
Peters, H. (2006). Using critical discourse analysis to illuminate power and knowledge in RPL. In P. Andersson \& J. Harris, (Eds.), Re-theorising the recognition of prior learning (pp. 163-182). Leicester, UK: National Institute of Adult Continuing Education.

Simmons, N. (2013). Outcomes of learning: [Dis]engaging students in higher education. In M. Kompf and P. M. Denicolo (Eds.) Critical issues in higher education (pp. 85-96). Rotterdam, Netherlands: SensePublishers.

Singh, M. (2010). Quality assurance in higher education: Which pasts to build on, what futures to contemplate? Quality in Higher Education, 16, 189-194.

Skolnik, M. L. (2010). Quality assurance in higher education as a political process. Higher Education Management and Policy, 22(1), 79-98.

Stensaker, B., \& Harvey, L. (2006). Old wine in new bottles? A comparison of public and private accreditation schemes in higher education. Higher Education Policy, 19(1), $65-85$.

Tremblay, K., Lalancette, D., \& Roseveare, D. (2012). THE rationale for an AHELO: Higher education in the 21st century context In Assessment of higher education learning outcomes: Feasibility study report. Volume 1-Design and implementation (pp. 15-38). Paris, France: OECD. Retrieved from http://www.oecd.org/edu/skills-beyond-school/ AHELOFSReportVolume1.pdf

Tuning Project (2008). Universities' contribution to the Bolgna process: An introduction (2nd ed.). Universidad de Deusto Bilbao Spain: J. González \& R. Wagenaar (Eds.). Retrieved from http://www.unideusto.org/tuningeu/images/stories/ Publications/ENGLISH_BROCHURE_FOR_WEBSITE.pdf

Weinrib, J., \& Jones, G. A. (2014). Largely a matter of degrees: Quality assurance and Canadian universities. Policy and Society, 33(3), 225-236.

\section{Contact Information}

Dietmar K. Kennepohl

Athabasca University

dietmark@athabascau.ca

Dietmar Kennepohl is professor of chemistry and former associate vice president academic at Athabasca University. His teaching experience has been mainly in a distributed and online setting, and he holds both university and national teaching awards. Over the years he has published and presented in the areas of chemistry and chemical education, as well as learning design, learning outcomes, assessment, PLAR, transfer credit, distance education, and emerging educational technologies. He was the winner of the Charles A. Wedemeyer Award for his book Accessible Elements (2010). 